\title{
Universiteit
}

Leiden

The Netherlands

\section{An African Muslim saint and his followers in France} Soares, B.F.

\section{Citation}

Soares, B. F. (2004). An African Muslim saint and his followers in France. Journal Of Ethnic And Migration Studies, 30(5), 913-927. Retrieved from https://hdl.handle.net/1887/9489

Version:

Not Applicable (or Unknown)

License:

Leiden University Non-exclusive license

Downloaded from: $\quad$ https://hdl.handle.net/1887/9489

Note: To cite this publication please use the final published version (if applicable). 


\title{
An African Muslim Saint and his Followers in France
}

\author{
Benjamin F. Soares
}

In this paper, I explore the practice of Islam among a relatively understudied group of Muslim migrants in France, the Halpulaaren, some of whom have been living in France for more than three decades. Drawing on field research in Senegal, Mali and France, I consider a Halpulaaren Muslim religious leader with a reputation as a living Muslim saint and his followers in France as a way to try to understand some of the ways of being Muslim in the shadow of the global city with both its promises and constraints.

Keywords: Halpulaaren; Islam; Racism; Transnationalism; West Africa

Over the past decade and a half, scholarly attention has increasingly turned to research on migrants in France and Muslim migrants in particular. As the largest group of Muslims in France, North Africans have not surprisingly received much of this attention. Research on West African Muslims in France has largely focused on the Soninke, the largest group of sub-Saharan Africans in France (see, for example, Quiminal 1991; Timera 1996 and, for West Africans in France more generally, Diouf 2002). In recent years, some of this research on Muslims in France has become increasingly journalistic or impressionistic (e.g. Kepel 2000) or focused much too narrowly on such topics as Muslim schoolgirls wearing headscarves. In much of this research, the treatment of Islam has been rather superficial. In this paper, I look at a relatively understudied group of West African Muslim migrants in France, the Halpulaaren (literally, 'those who speak Pulaar'). Drawing on field research in Senegal, Mali and France, I consider the contexts for Halpulaaren migration to France, including the West African background to such migration and the situation migrants face in France. I am particularly interested in understanding the practice of Islam and ways of being Muslim by Halpulaaren in what Hudita Mustafa has called 'the shadow of the global city.' ${ }^{1}$ I focus on a Halpulaaren Muslim religious leader with a reputation

Benjamin F. Soares is a Researcher at the African Studies Centre in Leiden. Correspondence to: Dr Benjamin Soares, African Studies Centre, PO Box 9555, 2300 RB Leiden, The Netherlands. E-mail: bsoares@ fsw.leidenuniv.nl 
as a living saint and try to understand the appeal of this saint for his many followers in France.

\section{A Transnational Muslim Religious Leader}

Mansour Baro is a long-standing and respected Senegalese Muslim religious leader in his seventies. ${ }^{2}$ A member of a prominent lineage of Muslim religious specialists (Pulaar, toroodbe), Mansour is one of the highest-profile members of the Toucouleur or Halpulaaren (Pulaar-speaking) community in Senegal. Many people refer to him as Tierno Mansour, using the title tierno in Pulaar, which means wise, learned or respected. Tierno Mansour usually lives with his family and many followers in M'Bour, a medium-sized, predominantly Wolof-speaking, urban centre and seaside resort to the south of the Senegalese capital, Dakar. That is, he resides in a place that is well beyond the Halpulaaren heartlands in the Senegal River valley of Senegal, Mauritania and Mali, the areas called Futa Toro and Futa Bundu.

The Sufi orders or the mystical paths in Islam have long been the main institutional forms for the practice of Islam in parts of West Africa. Despite the scholarly focus on the Mourides (see Riccio infra), the widespread assumption that Islam equals Mouridism in Senegal, even 'Mouridocentrism' in the study of Islam in Africa (see Triaud 1986), the Tijaniyya with its various branches and by the number of adherents constitutes the single largest grouping of Muslims in Senegal. In fact, the Tijaniyyawhose members call themselves Tijanis - is actually the most important Sufi order in West Africa. Tierno Mansour is one of a handful of the most esteemed leaders of the Tijaniyya Sufi order in Senegal. He is a leader of the branch of the Tijaniyya associated with Muhammad Sayyid Ba (d. 1980), the newest branch of the Tijaniyya in Senegal that can be dated to the 1930s. After studying with Amadou Baro (d. 1956), the father of Tierno Mansour, among others, Muhammad Sayyid Ba left the Senegal River valley to found a new community, Madina Gounasse, in the Casamance region of Senegal. ${ }^{3}$ Many Halpulaaren migrants subsequently moved from the Senegal River valley to be part of Muhammad Sayyid Ba's community of followers where they were able to cultivate land around the new settlement. Those associated with this branch of the Tijaniyya in Madina Gounasse, M'Bour, and elsewhere have developed a reputation for the rigorous practice of Islam, the pursuit of Islamic education, and hard work. Even though this branch of the Tijaniyya is comparatively new, it has grown in importance and influence due in no small part to the charisma of Muhammad Sayyid $\mathrm{Ba}$, his descendants, and close associates such as Tierno Mansour. Today, this branch of the Tijaniyya currently rivals other branches of the Sufi order based in such longstanding Senegalese centres of the Tijaniyya as Tivaouane and Kaolack. ${ }^{4}$

Tierno Mansour has personally initiated many people-literally thousands-into this branch of the Tijaniyya. Some of his many followers live in Senegal, as well as in neighbouring Mauritania, Mali, the Gambia, and beyond. Although his followers include French, Cape Verdean and Caribbean converts to Islam and a small number of French-born Muslims of North African origins, ${ }^{5}$ the overwhelming majority of his followers are Halpulaaren or speakers of Pulaar/Fulfulde. For example, in Mali his 
followers come from two main groups: Halpulaaren and Jawambe/Jogorame. The Halpulaaren or Futanke, as they often prefer to call themselves in Mali, are the descendants of those who moved to the region to take part in the nineteenth-century jihad associated with al-Hajj Umar Tall (d. 1864). A prominent Muslim cleric who hailed from the central valley of the Senegal River, the region of Futa Toro that straddles present-day Mauritania and Senegal, Umar Tall recruited followers, particularly from his natal region, to take up arms, building a state or empire that stretched across large parts of what is present-day Mali. The second group of his followers in Mali, Jawambe/Jogorame, often speak Pulaar/Fulfulde, but generally think of themselves as rather distinct from the Halpulaaren/Futanke. In France, Tierno Mansour is particularly popular among Halpulaaren migrants from Senegal and Mauritania (and to a lesser extent from Mali) who are (in the absence of census figures) estimated to be in the tens of thousands.

Most of the Halpulaaren living in France trace their origins to the central valley of the Senegal River, the region of Futa Toro. If the long history of this region has involved people of quite diverse social, ethnic and linguistic origins, Islam and the Pulaar language have over time helped people here imagine themselves as part of a distinctive community. ${ }^{6}$ In fact, the region has had a long history of the practice of Islam, traditions of Islamic education and scholarship, and the development of Islamic institutions over several centuries. Most notably, in the eighteenth century, Muslim clerics seized power and began to rule; in the nineteenth century, many from the region joined the jihad of Umar Tall. Many Halpulaaren today claim usually remote ancestry from the Fulbe with whom they associate a pastoralist way of life. Over time, many migrants to the region came from neighbouring areas and groups where Soninke, Jakhanke, Arabic and Wolof were spoken, and today many patronyms among the Halpulaaren index the diversity of their ancestry and origins. However, Pulaar has long been the main language spoken in the region of Futa Toro.

Ever since the nineteenth century, the Tijaniyya has been ascendant in the broader region. ${ }^{7}$ As a widely recognised leader of Tijaniyya, Umar Tall was an important catalyst for its spread in the region. But it was under French colonial rule during the first half of the twentieth century that there was mass affiliation to the Sufi order in large parts of West Africa and especially among the Halpulaaren. Today, for many Halpulaaren, to be Muslim necessarily means to be a member of the Tijaniyya or Tijani. Although the close association between the Halpulaaren and the Tijaniyya has not always entailed formal initiation into the Sufi order, it does usually mean great respect for this Sufi order, its leadership and hierarchy.

Many West African Muslims consider Tierno Mansour to be an exceptional Muslim religious leader. In fact, many consider him among the most exceptional religious leaders among the Halpulaaren. In this way, he is perhaps not unlike some of the many other West African Muslim religious leaders or marabouts (the term from the French colonial lexicon that has entered French and West African parlance) whom scholars have discussed (Cruise O’Brien 1971; Soares 1996, 1999, 2004a, forthcoming 2005). However, it is quite striking that many West Africans in France state quite emphatically that Tierno Mansour is not a marabout. In this way of thinking, 
marabouts are those persons who might try to make a living as diviners or amulet makers with a clientele in France largely, if not exclusively, comprised of non-Africans (see Kuczynski 2003). Interestingly, many Halpulaaren in France invoke the presumably more authentically Islamic term shaykh in Arabic when they talk about Tierno Mansour. But many refer to Tierno Mansour not only as a shaykh, but also as a living Muslim saint (in Arabic, wali). Many West African Muslims, like many Muslims throughout the world, think that certain persons are saints who are actually closer than ordinary Muslims to God or to the Prophet Muhammad.

While various Muslim religious leaders in West Africa have long made claims to religious authority based on some combination of hereditary charisma, reputations for knowledge, power, piety and/or miracles, Tierno Mansour is a new kind of religious figure. Indeed, Tierno Mansour is a transnational Muslim religious leaderwhat I would call a saintly superstar-who travels regularly to visit certain African migrants living outside of Africa. Although Tierno Mansour is just one of many such figures operating between Africa, Europe and North America, he has played a particularly important role in helping to redefine how to be Muslim away from Africa. ${ }^{8}$ In his case, this is directly tied to the long history of the Halpulaaren, their association with Islam and the Tijaniyya, and how they understand themselves as Halpulaaren and as migrants in France.

In 1974, Tierno Mansour made his first visit to France. It is worth remembering that in 1974 the world was in the middle of a major economic crisis; this was the era of 'stagflation', oil shocks, and rising unemployment rates. It was also just after the devastating 1972-73 drought and its aftermath in the West African Sahel. It is perhaps no coincidence that 1974 was also the year the French government implemented its first major restrictions on immigration. Ever since his first visit, Tierno Mansour has gone regularly to France to visit followers and potential followers from West Africa who had begun to arrive in considerable numbers in the 1960s to meet French labour shortages. During his early visits, Tierno Mansour spent most of his time in the immediate Paris region where many of his followers-young men-lived in planned workers' accommodation (so-called 'foyers', literally, homes, though more akin to hostels; Diop and Michalak 1996) close to their places of employment, such as automobile factories. But over the years, Tierno Mansour has extended his visits in length and in scope, venturing to other places in France, including Le Havre, Marseille and Nice, where there are large concentrations of West African migrants, particularly Halpulaaren. Over the years, many Halpulaaren men have brought wives from West Africa, and today many now have children who have been born or raised in France.

Over the past decade, Tierno Mansour has followed Halpulaaren migrants as they have found work and established bases elsewhere in Europe. In response to my questions about his travels, Tierno Mansour has told me on more than one occasion that he has 'carte blanche' as far as his visits to Europe are concerned. On recent trips, he has received and accepted invitations to visit migrants in Brussels and Antwerp in Belgium, in Cologne in Germany, and, most recently, in various places in Spain and Italy. Since the 1970s, the size of Tierno Mansour's entourage has increased such that there might be more than two dozen individuals, including his younger brothers, 
some of his sons, nephews and retainers from Senegal with him during his European tours. In recent years, these annual visits have usually lasted for at least six months. The French state is undoubtedly aware of the fact that the religious leader's entourage has become larger and his stays much longer. There are unsubstantiated rumours that the French state has even encouraged these developments, since they have occurred in an era of ever-tightening controls on immigration to France and much greater restrictions on the short-term visits of post-colonials.

\section{The Context of Migration}

Before trying to make sense of Tierno Mansour's appeal among Halpulaaren migrants in France, I must first present quite a bit of background information about the context for migration, the migrants themselves, and ways of being Muslim. While some Halpulaaren migrants have been employed as factory workers for decades in France, those with such coveted jobs are a small minority today. Indeed, beginning in the midto late 1970s, the economic position of many such West African migrants became much more precarious. Today, unemployment-both long and short term-is a recurrent problem for many migrants, especially men, regardless of country of origin. Racism is a major factor here that manifests itself unambiguously in discrimination in employment (see Adams and So 1996; Jules-Rosette 1998). It is quite difficult for most African migrants to get anything more than menial jobs in France. Even those with a university education, including those who have completed advanced studies and degrees, face chronic under- and unemployment. Taken as a whole, many, if not most, West African migrants (Halpulaaren or otherwise) are unskilled labourers in a variety of low-paying (and sometimes temporary or part-time) jobs_-street cleaners, janitors, kitchen staff at fast-food chains and Disneyland, and night watchmen - to name some of the most common jobs among my friends and informants.

However, such migrants do not just face economic uncertainty in France, but often difficult living conditions in overcrowded and substandard housing. While some Halpulaaren live within the city limits of Paris, the vast majority, especially those with families, live in la banlieue, the surrounding working-class suburbs, including several communities where there are particularly high concentrations of Halpulaaren living in apartment buildings in large rundown HLMs (habitation à loyer modéré), that is, lowcost public housing, roughly equivalent to council housing in the UK. When he is in France, Tierno Mansour often stays in a flat in one of the HLMs in a suburban Paris community. In fact, he and his entourage use such a place as a base for their travels around France and elsewhere in Europe.

It is important to consider Halpulaaren migration within the context of French attitudes towards Islam, Muslims, immigration and 'the Other'. French attitudes towards Islam and Muslims clearly relate to French colonial history, policies towards former colonies, and the long history of migration of Muslims from former colonies to the metropole: most importantly, North Africans to France. Arguably, French attitudes towards Islam and Muslims have historically been fundamentally ambivalent, and such ambivalence is intertwined with the history of laïité (or secularism) in 
France and the distinctive French republican tradition with its assimilationist ideals (Launay and Soares 1999). On the one hand, the laïc or secular French state financed the construction of the Paris mosque for Muslims in the 1920s and regularly bestowed favours on the colonial-authorised Muslim establishment in the colonies. On the other hand, the French state has severely restricted the building of mosques or even 'prayer rooms' in contemporary France where Muslims, usually from former colonies, might gather for collective prayer. However, in recent decades, a series of much-publicised events - the affaire du foulard in France and the Rushdie Affair-seem to signal that the long-standing ambivalence about Islam and Muslims has largely given way to antipathy for Islam and Muslims in France and in Europe more generally (see Asad 2003; Bowen 2003; Grillo supra; Salvatore infra).

Racism is also a factor in France where African migrants systematically encounter French republican assimilationist ideals that denigrate them for being both African and Muslim (c.f. Silverstein 2000). In a wide range of discourse in the public sphere, West African Muslims are singled out as having a particularly problematic place in French society. For instance, there are the many sans-papiers, those immigrants without legal status in France who are overwhelmingly West Africans, and whose situation garnered considerable attention in the 1990s as they fought to get papers to stay in the country. Although the sans-papiers and, by extension, West Africans sometimes received some sympathetic media coverage about their plight and the precariousness of their situation in France, West African migrants have been much less favourably discussed in the public sphere for their allegedly 'backward' practices such as female circumcision or excision and polygamy. While excision is usually represented as a particularly 'barbaric', 'African' practice (Mbow 2002), polygamy, another 'African' practice, is seen as the direct cause of both high birth and poverty rates among West Africans living in France. In recent years, the French government has taken steps to enforce bans on polygamy and excision. The French state's ability to intervene directly in African migrants' domestic arrangements, such as existing polygynous marriages, has never been straightforward, nor its policies applied in a systematic manner (Sargent and Cordell 2003). But with the changes in legislation, many polygynous West African families have experienced disruptions, such as difficulties in renewing residency permits and obstacles to family reunification and the visits of family members from Africa. The high-profile trial and conviction of West African women, who had performed or arranged excisions in France, has served to reinforce the already existing negative stereotypes of West Africans in France more generally.

Many of my Halpulaaren friends and informants point to how the French fail to understand them and quite often seek to punish them for some of their long-standing practices, such as polygamy and excision, which they see as either directly or indirectly tied to Islam. In this way, many articulate complaints about life in France invoking a notion of what is right or just. In fact, I have heard some point to the injustices Africans suffered under French colonial rule as sufficient justification for the multifarious ways in which they have been able to subvert attempts by the French state and its representatives to control them and their affairs. 
If African Muslim migrants experience French antipathy toward them and their place in the society, they also frequently encounter the racism of other Muslim migrants, particularly North Africans, in France. Since African Muslims sometimes work and share workers' accommodation, apartments and neighbourhoods with North African Muslims, this is the form of racism that is often most tangible to them. On numerous occasions, I have heard Halpulaaren complain about the insulting and demeaning way in which North Africans tend to speak to them and to treat them. Several Halpulaaren have told me how many North Africans automatically refer to West Africans by using derogatory terms in Arabic equivalent to nègre in French, erroneously thinking that West Africans would not understand, let alone take offence. West African Muslims also point to North Africans' pretensions about being more authentically Muslim than West African Muslims. Since many North African Muslims see themselves as Arabs and/or speak a dialect of Arabic, they frequently see themselves as having a privileged relationship with the religion of Islam. This is because the Prophet Muhammad was an Arab and Arabic was his language and that of the sacred text, the Quran. As many of my informants told me, it is not uncommon for North African migrants to refuse on principle to pray in a group if the imam, the person who leads communal prayers, is black. I have heard Halpulaaren complain that many of the North Africans with whom they interact are in fact not literate in Arabic and know much less about Islam than they do. But given their own very long association with the practice of Islam and Islamic education, Halpulaaren are unwilling to accept that they are in any way inferior to other Muslims or deficient in their knowledge of Islam. My informants and friends invariably pointed to such racism as the root cause of the many conflicts - major and minor-over worship, the organisation and running of 'prayer rooms' in workers' accommodation, and leadership of prayers they have had with North Africans in France. They also pointed to such racism as a main catalyst for conflict in all sorts of other non-religious areas in which the two groups have regular encounters.

Given some of these difficulties they face living in France, it is not surprising that many West African Muslims, including Halpulaaren, told me that they were only living in France 'temporarily'. This was a frequent refrain I have heard from many, including those who have been there for three decades or even longer. Be that as it may, many Halpulaaren also admitted that returning to West Africa permanently is quite simply out of the question. Many explicitly drew the comparison between their 'home' or 'land' (Pulaar, leeydi) in West Africa and what they called leeydi kaalis, literally, the land of money, whether France or elsewhere away from 'home' (see Riccio infra). Many pointed to the difficulties of making a living in West Africa and the never-lessening financial demands from those at home. Even those individuals who do anticipate eventually returning to West Africa say that it will not be until they reach retirement age and are able to return with some sort of pension or savings. This, they admit, has become more difficult in recent years with widespread unemployment, increased job insecurity, and difficulties in renewing residency permits.

If migrants in France have long been important for remittances to their home communities, continuing crises—structural adjustment, currency devaluation, polit- 
ical instability-in West Africa and tighter restrictions on migration to Europe have made them even more important for their potential access to money and resources. In many cases, migrants from the same villages in West Africa have founded associations in France that are used to channel funds and resources for various development initiatives, sometimes through 'sister city' schemes with French communities (see Daume 1998). However, Muslim religious leaders visiting from West Africa have also come to rely heavily upon migrants for sums of money more regular and substantial than those which most impoverished followers in West Africa can offer to them.

\section{Being Muslim in the 'Land of Money'}

Given the context of living in the shadow of the global city, it is interesting to consider some of the ways in which West African migrants have been expressing their identities in France. In fact, many explicitly assert their identities both as Muslims and as Africans. While students of Islamic 'fundamentalism' or political Islam would instruct us to look for signs of 'Islamism' or 'reformism' among such Muslim migrants (Westerlund and Rosander 1997), such 'reformist' or Islamist currents are rather thin on the ground. In fact, they seem to be almost completely absent among Halpulaaren migrants.

For most migrants, the assertion of a Muslim identity relates in part to the life course and the transition to adulthood. Among many West African Muslims in the Sahel, youth is thought to extend, especially for men, well into one's thirties. Before reaching adulthood, it is not uncommon for many young men not to perform their ritual daily prayers. In fact, I know many Halpulaaren in France and in West Africa who have told me that they spent ten years or even longer during their 'youth' without praying regularly. However, there is considerable pressure from peers and elders for those who reach adulthood-usually considered to begin with marriage - to exhibit some of the outward signs of Islam. Thus, all adults are generally expected to practice a standardised set of ritual norms - regular ritual daily prayer, fasting during the month of Ramadan, and, if circumstances permit, performance of the hajj, the pilgrimage to the Holy Cities (Soares 2004b). The standardised Islam Halpulaaren are expected to embrace as adults usually also entails either formal membership or more nominal attachment to the Tijaniyya. In practice, one is expected to have a religious leader who formally initiates one into the Sufi order. Some Halpulaaren told me that the experience of being an unmarried migrant so far away from 'home' for long periods helped to extend their youth much longer than would have been the case had they not been migrants. The same applies for those migrants married to wives who have remained in West Africa. Given that these men might not see their wives for several years at a time, their status was equivalent to quasi-adulthood. In any case, both married and unmarried Halpulaaren migrants regularly fail to perform their ritual daily prayers for extended periods of time. Moreover, during the period of youth, very few seek formal initiation into the Tijaniyya. In addition, many have told me about some of their other behaviour during their youth in France they considered unIslamic, most notably, drinking alcohol and extra-marital sexual relations. 
However, it is interesting to note that the assertion of a Muslim identity among Halpulaaren in France often goes beyond the standardised ritual norms of prayer and fasting to include new ways of exhibiting one's ostensible piety more publicly (Salvatore 1998). For example, those who may have drunk alcohol in their 'youth' or 'chased women' abstain from doing so (at least publicly) as 'adults'. In addition, many adult men grow beards, and some carry prayer beads, which index them as Muslims and usually Tijanis. Many Halpulaaren women wear a rather distinctive head covering of bright, plain or printed cotton fabric_rather unlike those of North African/ Maghrebi or Turkish women-when they are in public. When they are not working, both men and women will often wear various forms of dress-long robes, the West African boubou in particular. These are not necessarily generically Muslim symbols (Eickelman and Piscatori 1996), but rather symbols that are recognisable to them (and sometimes to others) as both African and Muslim.

During fieldwork, many of my informants explained to me that they did not think that their children could ever receive a proper moral and religious education in France. Although I know one young French-born man in his twenties, an unemployed mechanic living outside Paris, who studied the Quran with his Senegalese-born father and eventually memorised the entire Quran, this is quite exceptional. The children of West African migrants very rarely receive more than a rudimentary Islamic religious education in France. The difficulties of giving a proper moral and religious education to one's children were a cause for considerable concern and much discussion, especially among those who live in areas with social problems. People regularly expressed concern about such dangers as drug use, school truancy and juvenile delinquency, as well as the dangers of their children not practising Islam. I know many migrants who have sent their young children, sometimes along with their mothers, back to West Africa to be raised and educated. The children sent back to West Africa sometimes attend private Islamic educational institutions where Arabic is the main language of instruction. Several informants also explained how they had sent their French-born teenage sons for a 'proper', advanced Islamic education in West Africaan education they hoped would be similar to their own education in the 1940s, 1950s and 1960s. Despite such nostalgia about the past, it is quite clear that 'traditional' Islamic education has been undergoing considerable changes with, for example, pedagogical techniques and curriculum changes being borrowed from both madrasas and French-language secular schools. I know of several cases where migrants have sent their young sons to Tierno Mansour in Senegal for their education. Their hope, several explained, was that upon completion of advanced Islamic studies-including thorough knowledge of jurisprudence (fiqh) - they would return to France and become teachers for the other children of West African migrants. It was a commonly expressed view that their sons who were born in France, but educated about Islam in Africa, would be better suited than themselves (who might not have perfect command of French) to communicate with the other children of migrants born and raised in France. Moreover, it is expected that they will be able to help to convey to them the correct 'African' and 'Muslim' values the parents would like. Of course how such 
second-generation Halpulaaren in France relate to 'home' and its values so many of their parents invoke with nostalgia remains to be seen.

\section{The Saint's Appeal}

For many, if not most, migrants, there have been more regular interactions with visiting West African religious leaders. In some cases, there is a heightened veneration of such religious leaders. As migration of West Africans to France and elsewhere has become more permanent, various Muslim religious leaders from all the major Sufi orders in West Africa have undertaken tours in order to visit migrants in Europe and increasingly in North America. This brings me back to the question of the appeal of Tierno Mansour with his own annual visit to Europe.

Many Halpulaaren migrants in France readily talk about Tierno Mansour as a moral exemplar, who embodies certain positive values - exceptional piety and a particularly strong commitment to Islam. This is exhibited most clearly in his public statements about the correct practice of Islam, particularly the standardised ritual norms, and the absolute importance of moral rectitude, honesty, and treating other people well. Given the difficulties of upholding such values in republican and laï France, many West African migrants have increasingly turned to such visiting religious leaders (of whom Tierno Mansour is just one of the most prominent) for succour-blessings, prayers, and guidance on the practice of Islam in the West. I have met many Halpulaaren migrants who have told me how they have sought out Tierno Mansour when he is visiting Europe because they so appreciate the leadership, guidance and blessings he provides. Every year, more Halpulaaren have extended formal invitations to Tierno Mansour to visit them where they are living in different places in France, and beyond.

I have been struck by the fact that so many Halpulaaren migrants credit Tierno Mansour personally with their own new-found commitment to the practice of Islam and the Tijaniyya. Many talk about him as having rescued them from a life of iniquity. I have heard many of his followers in France explain how in their youth while living in France many of them were not good Muslims at all. As they explained, many did not pray regularly, they drank alcohol, and they 'chased' women. In many cases, such behaviour continued well beyond the age when it may have been permitted or at least overlooked back at 'home' in West Africa. In remarkably similar narratives, many Halpulaaren have recounted to me that when Tierno Mansour came to France, they told him about their own behaviour or that of their peers. In turn, they listened to what he had to say about the practice of Islam, and they were able to be proper Muslims. Many emphasised that it was because of Tierno Mansour that they completely changed. They began to pray regularly, fast during the month of Ramadan, and even formally joined the Tijaniyya. Tierno Mansour has initiated many of these Halpulaaren in France into the Tijaniyya. Some even suggest that Tierno Mansour has been directly responsible for the greater commitment to Islam on the part of all Halpulaaren living in France. Although none of my informants referred to these individual or collective changes as 'miracles', for many of them, Tierno Mansour's role in the greater commitment to the practice of Islam was an unambiguous sign he is a 
saint. In fact, many of my friends and informants refer without hesitation to Tierno Mansour as a living Muslim saint.

Tierno Mansour's appeal among Halpulaaren relates to his charisma, which is in part based on hereditary sanctity, but also on his own religious authority and reputation as an individual Muslim religious leader. His status as a member of a lineage of Muslim religious specialists is key to his appeal. His father also had a saintly reputation, and the illustrious history of their lineage is firmly rooted in the long history of the Halpulaaren and the practice of Islam and the Tijaniyya in West Africa. Since there are so many descendants of lineages of Muslim religious specialists back at 'home' and even among Halpulaaren migrants, such hereditary sanctity is not enough to ensure an individual Muslim religious leader's appeal. In fact, Tierno Mansour seems to be quite a special case. Not only has he maintained his vocation as a Muslim religious specialist_unlike most migrants with similar backgrounds-but he has developed a widespread reputation as a saint. This occurred during the period in which he was regularly visiting Halpulaaren in France. For many Halpulaaren migrants, Tierno Mansour helps them to recall 'home' with which they often associate Islam and learned and charismatic religious leaders like Tierno Mansour. It is an undeniable fact that Tierno Mansour's religious authority has grown considerably stronger both at 'home' and in 'the land of money' in the decades since he first visited France. In some cases, this has been to the dismay of rival Muslim religious leaders and their followers who are unhappy about his influence, which shows no signs of diminishing.

Once a year, Tierno Mansour hosts an annual visit with his followers in France. This gathering is usually in the month of July in a suburb of Paris and is called the daaka. Interestingly, this term in Pulaar is associated with nomadism or pastoralism, the way of life many Halpulaaren claim was that of their putative Fulbe ancestors. Daaka means to go some place temporarily, which is of course how many Halpulaaren describe their situation in France. Although Tierno Mansour's branch of the Tijaniyya has held a daaka in Madina Gounasse every year for several decades, the first daaka in France was held in 1994. Since that time, smaller daakas have been initiated in other places in France, Belgium, and Germany. The annual gathering in France provides a rare opportunity for many Halpulaaren migrants to meet together and to socialise away from the routines of everyday life in 'the land of money'.

In 1999, when I attended the daaka in France, there were thousands of Halpulaaren men who gathered in a large parc des expositions or convention centre in suburban Paris over several days. One of the most striking features of the daaka is the complete absence of participants who are women. With the objective of gender segregation in view, Tierno Mansour does not allow women to be present. This is enforced to the extent that all work ordinarily considered women's work-cooking, serving food and beverages, and cleaning - is carried out by men during the daaka. Over several days, Halpulaaren men coming from all over France, Belgium and the Netherlands gather at the daaka where they pray the ritual daily prayers together, recite the special litanies of the Tijaniyya, listen to announcements by Tierno Mansour and his associates, socialise, eat meals together, and sometimes spend the night sleeping on the floor of 
the convention centre. While all of the prayers and the special litanies of the Tijaniyya are in Arabic, almost all of the public speaking is in Pulaar.

During much of the daaka, Tierno Mansour and his close associates are the centre of everyone's attention. Many of the men, following the example of Tierno Mansour, fast from sunrise to sunset, which given how late the sun sets in summer is not easy for many. Some bring their young sons with them and ask Tierno Mansour, his brothers and sons to bless them. This they usually do by placing the right hand on the boys' heads. I have watched as many men have approached to kiss Tierno Mansour's hand or his shoulder, ways of showing respect. Toward the end of each communal meal, Tierno Mansour spends quite a bit of time picking up food in his right hand that he passes to his followers who then eat it, thereby indexing their close relationship to him.

Many of those in attendance are close followers of Tierno Mansour, and some even plan their annual paid leave to coincide with the daaka. Others in attendance are not necessarily his followers in any formal sense. Many attend in the hope of asking for his blessings so that they might be able to find work or resolve a personal problem. Most in attendance listen attentively to what Tierno Mansour has to say during the daaka or on other occasions when they might see him, for example at Friday prayers in a local mosque or in a 'prayer room' where he might address them after communal prayers. Tierno Mansour encourages people to practice Islam correctly, particularly the standardised set of ritual norms. He reminds them that if they stop drinking alcohol, then they remain Muslims, but only if they pray, fast during Ramadan, and so forth. He also instructs them to obey the laws of France and to avoid involvement in politics. While no one would contest what Tierno Mansour says about the standardised ritual norms or the prohibition on the consumption of alcohol, it is not always easy to follow some of his other prescriptions. Just like other groups of West Africans living in France, many among Halpulaaren migrants are undocumented workers who, by their very presence in France, are not obeying laws about which they often know a great deal. But even many of those whose legal status is not precarious are openly critical of a country whose laws sometimes adversely affect them, their families and communities in many different ways. Moreover, many Halpulaaren living in France are also involved in one way or another in politics at 'home' in Senegal and Mauritania, and thus they do not heed the religious leader's advice.

During the daaka, there does seem to be a sense that all Halpulaaren men are equal and united. Whether they were born, raised or studied in Senegal, Mauritania or Mali is unimportant. What is important is that they all identify with their 'home' in West Africa. Almost everyone present speaks Pulaar, and all are ostensibly Muslims. But there are important differences between those in attendance, most notably between the Muslim saint and the others present. The latter range from his close and devoted followers to lapsed or potential new followers to those more agnostic about him. There are also important differences between those persons of different hereditary social categories in Halpulaaren society, whether from free-born lineages, slave or 'caste' origins. All are aware that these differences continue to be salient such that marriage alliances in Tierno Mansour's family are only with certain subgroups of free-born persons from lineages of Muslim religious specialists. This is the same subgroup from 
which all his appointed deputies of the Tijaniyya, including those living in Europe, come. There are also large differences in income, which might even permit us to talk about class differences between migrants, some of whom are destitute while others have the means to perform the hajj more than once. Such differences notwithstanding, for many Halpulaaren the recalling of 'home' seems to be one of the most important features of interactions with Tierno Mansour in the 'land of money'.

If one takes some of the ways of being Muslim and being Halpulaaren in Franceexhibiting one's piety publicly, sending one's children to West Africa for education, and meeting visiting religious leaders like Tierno Mansour-together, they help to index these African Muslims' differences both from their French hosts, as well as from the large North African Muslim communities in France (Kepel 1987). Moreover, meeting with such a prominent Halpulaaren religious leader also helps to index their own differences from the many other West African Muslims living in France whose own religious leaders, whether Tijani or Mouride, usually make their own regular visits to Europe.

As I have tried to suggest, Tierno Mansour's appeal is closely tied to his charisma, both his hereditary sanctity, as well as to his own individual reputation as a saint. But his reputation as a saint is one that is quite novel, that of a transnational Muslim religious leader who travels regularly between West Africa and Europe. If some of his closest Halpulaaren followers in France credit him with their own heightened commitment to the practice of Islam, many others are drawn to Tierno Mansour because of his saintly reputation and the blessings they anticipate. Most readily acknowledge that it is only someone truly exceptional-a transnational saintly superstar-who is able to bring thousands of Halpulaaren together in France in the interest of Islam and the Tijaniyya. Such a saintly superstar, known for the rigorous practice of Islam and the wisdom he so freely imparts to others, provides comfort and blessings to many Halpulaaren who have often found it difficult to live in France. Indeed, one of the great concerns of Halpulaaren migrants has been to remain committed to the practice of Islam and the Tijaniyya and to pass this on to one's family. In the end, for many Halpulaaren, the recalling of 'home' is probably much more important than any particular guidance or advice-which some do not, probably cannot, follow-from the saint. This is just some of the complexity of the experience of these West African Muslim migrants who, together with such an African Muslim saint, a transnational saintly superstar, are helping to redefine their identities-African, Muslim, Halpulaaren and Tijani-in the shadow of the global city with both its promises and constraints.

\section{Acknowledgements}

This paper draws on fieldwork in Senegal, Mali and France between 1991 and 2003 and particularly from a 12-month period from 1998 to 1999 in France. I am most grateful to my Paris-based Mauritanian colleague, Ibrahima Abou Sall (EHESS), for our many exchanges and conversations about this project and for introductions to 
many Halpulaaren in France. In rewriting the paper, I have benefited from comments from Ralph Grillo and Mirjam de Bruijn.

\section{Notes}

[1] This is from Mustafa's (2001) reading of Sassen (2001).

[2] I follow his orthographic self-presentation. Following more recent orthographic conventions, his name would be Ceerno Mansur Baaro. Although I have written about some of his activities in Mali (e.g. Soares forthcoming 2005), my first meeting with Tierno Mansour was in 1998 in Bamako, Mali. I have subsequently met with him on various occasions in France in 1999, later in the same year in M'Bour, Senegal, and most recently in France in 2002 and in 2003.

[3] See Wane (1974) and Sow (1986) for a discussion of Tierno Muhammad Sayyid Ba and the community he founded in Madina Gounasse. For a recent discussion of Madina Gounasse, see van Hoven (1999) and N'Gaïdé (2002).

[4] I am unable to discuss the different branches of the Tijaniyya or address differences over ritual practice and doctrine. See Seesemann and Soares (forthcoming).

[5] I met followers from some of these places in France and in Senegal. In Senegal, I also met a few followers from Ghana and Guinea Bissau.

[6] Breedveld and de Bruijn's (1996) critique of images of the Fulbe is particularly relevant to this discussion.

[7] On this history, see Robinson (1985) and especially Sall (2000) on the spread of the Tijaniyya.

[8] See Werbner's particularly important work on South Asian saints and Sufis (e.g. Werbner 1995).

\section{References}

Adams, A. and So, J. (1996) A Claim to Land by the River: A Household in Senegal, 1720-1994. Oxford: Oxford University Press.

Asad, T. (2003) 'Muslims as a "religious minority" in Europe', in Asad, T. (ed.) Formations of the Secular: Christianity, Islam, Modernity. Stanford: Stanford University Press, 159-80.

Bowen, J. (2003) 'Two approaches to rights and religion in contemporary France', in Mitchell, J. and Wilson, R. (eds) Rights in Global Perspective. London: Routledge, 33-53.

Breedveld, A. and de Bruijn, M. (1996) 'L'image des Fulbe: analyse critique de la construction du concept de "pulaaku", Cahiers d'Études Africaines, 36: 791-821.

Cruise O'Brien, D.B. (1971) The Mourides of Senegal. Oxford: Clarendon Press.

Daume, C. (1998) Les Associations Maliens en France: migration, développement et citoyenneté. Paris: Karthala.

Diop, M. and Michalak, L. (1996) "Refuge" and "prison": Islam, ethnicity, and the adaptation of space in workers' housing in France', in Metcalf, B.D. (ed.) Making Muslim Space in North America and Europe. Berkeley: University of California Press, 74-91.

Diouf, S.A. (2002) 'Invisible Muslims: the Sahelians in France', in Haddad, Y.Y. and Smith, J.I. (eds) Muslim Minorities in the West. Lanham, MA: Altamira Press, 145-59.

Eickelman, D.F. and Piscatori, J. (1996) Muslim Politics. Princeton: Princeton University Press.

Jules-Rosette, B. (1998) Black Paris: The African Writers' Landscape. Urbana and Chicago: University of Illinois Press.

Kepel, G. (1987) Les Banlieues de l'Islam. Paris: Le Seuil.

Kepel, G. (2000) Jihad: expansion et déclin de l'islamisme. Mesnil-sur-l'Estrée: Gallimard.

Kuczynski, L. (2003) Les Marabouts Africains à Paris. Paris: CNRS Éditions.

Launay, R. and Soares, B.F. (1999) 'The formation of an "Islamic sphere" in French Colonial West Africa', Economy and Society, 28(4): 497-519. 
Mbow, P. (2002) 'Pénaliser un fait culturel: quelle solution à l'excision?', Présence Africaine, 160: $67-77$.

Mustafa, H.N. (2001) 'In the shadow of the global city'. Washington, DC: Paper presented to the annual meeting of the American Anthropological Association, 28 November.

N'Gaïdé, A. (2002) 'Les marabouts face à la "modernité", in Diop, M.C. (ed.) Le Sénégal Contemporain. Paris: Karthala, 617-52.

Quiminal, C. (1991) Gens d'Ici et Gens d'Ailleurs: migrations Soninké et transformations villageoises. Paris: Christian Bourgois.

Robinson, D. (1985) The Holy War of Umar Tal. Oxford: Clarendon Press.

Sall, I.A. (2000) 'La diffusion de la Tijaniyya au Fuuta Toro (Mauritanie-Sénégal)', in Triaud, J.-L. and Robinson, D. (eds) La Tijaniyya: Une confrérie musulmane à la conquête de l'Afrique. Paris: Karthala, 367-92.

Salvatore, A. (1998) 'Staging virtue: the disembodiment of self-correctness and the making of Islam as public norm', Yearbook of the Sociology of Islam, 1: 87-119.

Sargent, C. and Cordell, D. (2003) 'Polygamy, disrupted reproduction, and the state: Malian migrants in Paris, France', Social Science \& Medicine, 56(9): 1961-72.

Sassen, S. (2001) The Global City: New York, London, Tokyo. Princeton: Princeton University Press (2nd edition).

Seesemann, R. and Soares, B.F. (forthcoming) "Being as good Muslims as Frenchmen”: on Islam and colonial modernity in West Africa', in Hanson, J.H. and van Dijk, R. (eds) Religious Modernities in West Africa. Bloomington: Indiana University Press (in press).

Silverstein, P.A. (2000) 'Islam, soccer, and the French nation-state', Social Text, 18(4): 25-53.

Soares, B.F. (1996) 'A contemporary Malian shaykh', Islam et Sociétés au Sud du Sahara, 10: 145-53.

Soares, B.F. (1999) 'Muslim proselytization as purification', in An-Na'im, A.A. (ed.) Proselytization and Communal Self-Determination in Africa. Maryknoll: Orbis, 228-45.

Soares, B.F. (2004a) 'Muslim saints in the age of neoliberalism', in Weiss, B. (ed.) Producing African Futures: Ritual and Reproduction in a Neoliberal Age. Leiden: Brill.

Soares, B.F. (2004b) 'Islam and public piety in Mali', in Salvatore, A. and Eickelman, D.E. (eds) Public Islam and the Common Good. Leiden: Brill, 205-26.

Soares, B.F. (forthcoming 2005) The Prayer Economy in a Malian Town. Edinburgh: Edinburgh University Press for the International African Institute (in press).

Sow, D. (1986) Contribution à l'Etude de l'Islam en Afrique. La communauté Tijani de Madiina Gunaas. Nouakchott: Université de Nouakchott, Mauritania, unpublished MA dissertation.

Timera, M. (1996) Les Soninké en France. Paris: Karthala.

Triaud, J.-L. (1986) 'Le thème confrérique en Afrique de l'ouest', in Popovic, A. and Veinstein, G. (eds) Les Ordres Mystiques dans l'Islam: Cheminements et situation actuelle. Paris: Éditions de l'EHESS, 271-82.

van Hoven, E. (1999) 'Medina Gounass: the end of a religious isolate', ISIM Newsletter, 4: 25.

Wane, Y. (1974) 'Ceerno Muhamadu Sayid Baa ou le soufisme intégral de Madiina Gunaas (Sénégal)', Cahiers d'Études Africaines, 14(4): 671-98.

Werbner, P. (1995) 'Powerful knowledge in a global Sufi cult', in James, W. (ed.) The Pursuit of Certainty. London: Routledge, 134-60.

Westerlund, D. and Rosander, E.E. (eds) (1997) African Islam and Islam in Africa: Encounters between Sufis and Islamists. Athens: Ohio University Press. 
